\title{
PENGINFORMASIAN POTENSI DESA WISATA BERBASIS WEBLOG DI NAGARI KOTO RANTANG KECAMATAN PALUPUAH KABUPATEN AGAM
}

\author{
Ary Satria Nasrul ${ }^{1}$,Ratna Wilis ${ }^{2}$ \\ Program Studi Geografi, \\ Falkutas Ilmu Sosial, Universitas Negeri Padang \\ Email : ariesatrianasrul13@gmail.com
}

\begin{abstract}
ABSTRAK
Tujuan dari penelitian ini adalah untuk mengetahui potensi wisata yang ada di Nagari Koto Rantang dan bentuk weblog desa wisata Nagari Koto Rantang untuk menginformasikan potensi wisata. Jenis penelitian ini adalah penelitian deskriptif kualitatif. Teknik pengumpulan data diperoleh dari hasil dokumentasi dan hasil wawancara dengan informan kunci dilapangan. Teknik keabsahan data yang digunakan dalam penelitian ini adalah metode triangulasi. Teknik analisis data terdiri dari pengumpulan data, reduksi data, display data kemudian dilakukan verifikasi data atau penarikan kesimpulan. Hasil penelitian memperlihatkan bahwa (1) potensi wisata yang dimiliki Nagari Koto Rantang terdiri dari Objek wisata bunga raflesia, wisata kuliner kopi luwak, wisata panorama, pembuatan jalur trabas dan kegiatan agrowisata, dan wisata pendidikan LAPAN dan BMKG, (2) setelah menemukan potensi wisata, kemudian dibuat weblog pariwisata guna memberikan informasi terkait dengan kegiatan pariwisata yang ada di Nagari Koto Rantang.
\end{abstract}

Kata Kunci: Desa wisata, weblog

\section{Abstract}

The purpose of this study is to determine the potential of existing tourism in Nagari Koto Rantang and weblog village village tour Nagari Koto Rantang to inform the potential of tourism.The type of this research is qualitative descriptive research. Technique of collecting data obtained from result of documentation and result of interview with key informant in field. The technique of data validity used in this research is triangulation method. Data analysis techniques consist of data collection, data reduction, data display then data verification or conclusion. The result of the research shows that (1) the tourism potential of Nagari Koto Rantang consists of Raflesia flower attraction, civet coffee tour, panoramic tour, trabas and agro tourism, and LAPAN and BMKG education tour, (2) after finding the tourism potential, then made a tourism weblog to provide information related to tourism activities in Nagari Koto Rantang.

Keywords: tourist village, weblog

${ }^{1}$ Mahasiswa Geografi Fakultas Ilmu Sosial Universitas Negeri Padang

${ }^{2}$ Dosen Geografi Fakultas Ilmu Sosial Universitas Negeri Padang. Ahyuni, ST, M.Si, Ratna Wilis, S.Pd, MP 


\section{PENDAHULUAN}

Menurut Undang-undang Nomor 10 Tahun 2009 tentang kepariwisataan yang dimaksud dengan wisata adalah kegiatan perjalanan yang dilakukan oleh seseorang atau sekelompok orang dengan mengunjungi tempat tertentu untuk tujuan rekreasi, pengembangan pribadi, atau mempelajari keunikan daya tarik wisata yang dikunjungi dalam jangka waktu sementara. Sedangkan pariwisata adalah berbagai macam kegiatan wisata dan didukung berbagai fasilitas serta layanan yang disediakan oleh masyarakat, pengusaha, dan pemerintah.

Menurut Pariwisata Inti Rakyat (PIR), yang dimaksud dengan Desa Wisata adalah : Suatu kawasan pedesaan yang menawarkan keseluruhan suasana yang mencerminkan keaslian pedesaan baik dari kehidupan sosial ekonomi, sosial budaya, adat istiadat, keseharian, memiliki arsitektur bangunan dan struktur tata ruang desa yang khas, atau kegiatan perekonomian yang unik dan menarik serta mempunyai potensi untuk dikembangkannya berbagai komponen kepariwisataan, misalnya : atraksi, akomodasi, makanan-minuman, dan kebutuhan wisata lainnya (Mulyadin, 2001).

Pengembangan wisata daerah perdesaan merupakan dampak adanya perubahan minat wisatawan terhadap daerah destinasi wisata. Tumbuhnya kecendrungan dan motivasi wisata khusus yang menginginkan wisata yang kembali ke alam, interaksi dengan masyarakat lokal, serta tertarik untuk mempelajari keunikan budaya lokal sehingga mendorong pembangunan wisata daerah perdesaan. Obyek wisata yang ada di daerah perdesaan merupakan suatu desa yang mempunyai sarana yang mendukung kegiatan kepariwisataan dan dikembangkan menjadi obyek wisata baru (Edwin, 2015).

Seiring dengan kemajuan teknologi informasi dimana peranan website internet menjadi kebutuhan utama dalam pemberian informasi tercepat di era globlisasi. Pengembangan desa wisata berbasis weblog merupakan salah satu upaya dalam pengembangan desa wisata, dimana weblog dapat dijadikan media dalam mempromosikan objek wisata suatu daerah. Blog atau weblog menampilkan publikasi online instan dan mengajak publik untuk membaca dan memberikan umpan balik terhadap isi blog.

Nagari Koto Rantang merupakan salah satu nagari di Kabupaten Agam Provinsi Sumatera Barat yang memiliki potensi pariwisata yang dapat dikembangkan. Kegiatan wisata yang sangat berpotensi di daerah tersebut salah satunya adalah wisata alam Bunga Raflesia. Menurut Hadi Suryadi selaku Kepala Dinas Pariwisata Pemuda dan Olahraga Kabupaten Agam mengatakan, aktivitas pelaku wisata di kawasan yang semakin dibanjiri wisatawan mncanegara dan nusantara ini sebelumnya belum terorganisir. Namun, saat ini kegiatan tersebut semakin meningkat dengan terbentuknya kelompok Sadar Wisata (Pokdarwis) Koto Rantang Adventure pada tanggal 29 Maret 2017. Tujuan 
terbentuk kelompok ini agar masyarakat setempat memahami bahwa potensi yang ada perlu di kembangkan dan dikelola dengan baik karena pemanfaatnya adalah masyarakat itu sendiri. Semakin banyak wisatawan yang datang, maka semakin besar peluang usaha yang bisa diciptakan sesuai dengan kebutuhan wisatawan yang mencari kenyamanan (Ramadan, 2017).

Desa wisata dibentuk untuk memperdayakan masyarakat agar dapat berperan sebagai pelaku dalam upaya meningkatkan kesiapan dan kepedulian dalam menyikapi potensi pariwisata dan berperan sebagai tuan rumah yang baik bagi wisatawan yang berkunjung serta memiliki kesadaran akan peluang dan kesiapan dalam mengambil manfaat yang dapat dikembangkan dari kegiatan pariwisata untuk meningkatkan kesejahteraan ekonomi masyarakat.

Salah satu cara dalam pengembangan desa wisata bisa dilakukan dengan pembentukan weblog. Weblog wisata suatu daerah bisa berisikan tentang informasi kegiatan pariwisata suatu daerah, seperti peta perjalanan wisata, jarak tempuh menuju objek wisata, jenis objek wisata yang dimiliki, serta perkiraan biaya yang dibutuhkan saat melakukan kegiatan wisata didaerah tersebut.

Penelitian lebih lanjut perlu dilakukan dengan tujuan untuk mengetahui 1) potensi wisata yang ada di Nagari Koto Rantang dan 2) bentuk Weblog desa wisata Nagari Koto Rantang untuk menginformasikan potensi wisata. Penelitian ini diharapkan dapat menjadi acuan dalam penginformasian desa wisata di nagari tersebut. Maka diangkat penelitian dengan judul "Penginformasian Desa Wisata Berbasis Weblog Di Nagari Koto Rantang Kecamatan Palupuah Kabupaten Agam".

\section{METODE PENELITIAN}

Penelitian ini merupakan penelitian deskriptif kualitatif dengan maksud untuk memperoleh informasi mengenai wisata yang ada di Nagari Koto Rantang.

Teknik pengumpulan data yang digunakan dalam penelitian ini adalah teknik wawancara dengan menggunakan informen kunci dan dokumentasi.

Berdasarkan kebutuhan data dalam penelitian, peneliti memilih informan yang dianggap memiliki pemahaman dan mengetahui lebih mengenai kondisi dan keadaan Nagari Koto Rantang terutama dalam bidang pariwisata. Oleh sebab itu, peneliti mengambil informan kunci sebanyak 4 orang yang terdiri dari : Wali Nagari, Wali Jorong, angkota POKDARWIS dan Niniak Mamak.

Berdasarkan teknik pengumpulan data yang digunakan, maka instrumen penelitian ini menggunakan berupa panduan wawancara dan panduan dokumentasi.

Dalam penelitian ini untuk mendapatkan keabsahan data dilakukan dengan triangulasi data. Triangulasi dengan sumber yang dilaksanakan pada penelitian ini yaitu membandingkan hasil wawancara dengan isi dokumen yang berkaitan dengan penelitian.

Analisis data hasil wawancara dan dokumentasi pengembangan desa 
wisata Nagari Koto Rantang yang digunakan dalam penelitian ini adalah menggunakan analisis kualitatif dengan langkah-langkah seperti : pengumpulan data, reduksi data, display data dan verifikasi data (Purnomo, 2015).

\section{HASIL DAN PEMBAHASAN}

Nagari Koto Rantang adalah sebuah Nagari yang terletak pada Kecamatan Palupuah, kabupaten Agam, provinsi Sumatera Barat, Indonesia. Berdasarkan letak astronomis Nagari Koto Rantang terletak diantara 00010'00" LS - 00017'00" LS dan 100017'30" BT - 100024'30" BT. Luas wilayah Nagari Koto Rantang adalah 42,87 km2 atau sekitar 18,08 persen dari luas Kecamatan Palupuah. Informasi selanjutnya dijelaskan pada gambar 1 yaitu peta lokasi penelitian.

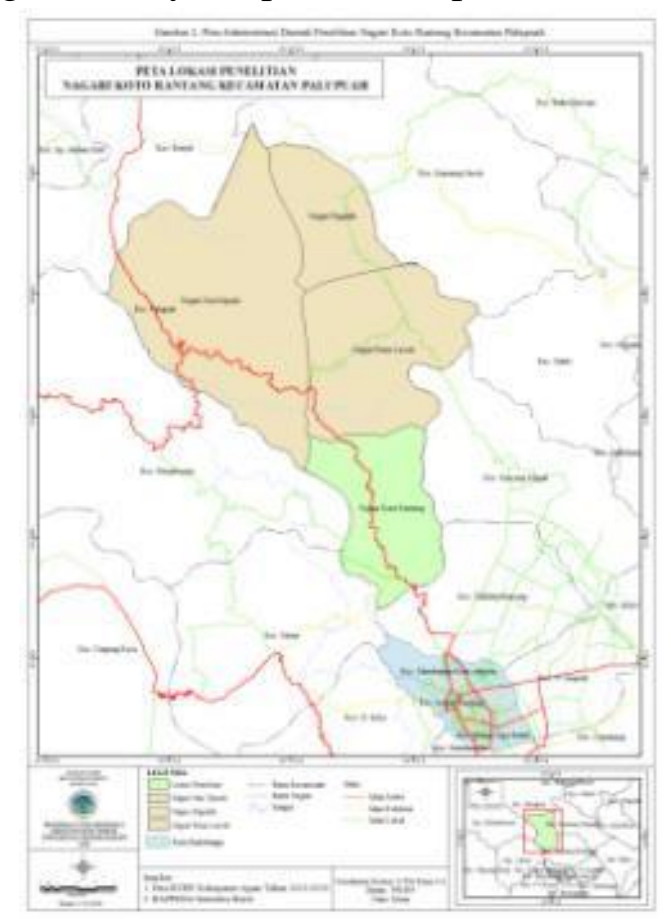

Gambar 1. Peta Lokasi Penelitian (Sumber : BAPPEDA Kabupaten Agam)

\section{Hasil Wawancara Objek Wisata Nagari Koto Rantang}

Nagari Koto Rantang merupakan nagari yang memiliki topografi berupa perbukitan yang didominasi dengan penggunaan lahan berupa hutan, sehingga Nagari Koto Rantang memiliki pemandangan alam yang indah dan juga udara yang sejuk serta segar. Nagari Koto Rantang juga memiliki potensi wisata alam, budaya maupun buatan yang dapat di kembangkan, seperti yang disebutkan dalam wawancara mengenai potensi wisata Nagari Koto Rantang berikut ini :

a. Hasil Wawancara Bersama Wali Nagari

Berdasarkan hasil wawancara yang peneliti lakukan bersama Bapak "SY. Datuak Batuduang Dilangik" sebagai pimpinan tertinggi di Nagari Koto mengenai potensi wisata yang dimiliki nagari tersebut adalah sebagai berikut:

"Sebenarnya banyak potensi wisata yang bisa dikembangkan di Nagari Koto Rantang ini, seperti bunga raflesia untuk wisata alam, pembuatan jalur trabas sekaligus pembuatan kegiatan agrowisata, kopi luwak untuk wisata kuliner, serta wisata pendidikan yang sudah dijalin kerja sama dengan pihak BMKG dan LAPAN, selain itu nagari ini mendapat julukan sebagai nagari madani sehingga kami berencana ingin menghidupkan kembali surau madani untuk tempat belajar agama dan adat yang ada disini nak".

Berdasarkan hasil wawancara, maka dapat disimpulkan bahwa menurut bapak SY Datuak Batuduang Dilangik 
potensi wisata yang ada di Nagari Koto Rantang berupa :

1) Objek wisata bunga raflesia

2) Wisata kuliner kopi luwak

3) Kegiatan wisata motor trail (trabas)

4) Kegiatan agrowisata

5) Wisata pendidikan BMKG dan LAPAN

6) Surau madani

Gambar 2 merupakan peta potensi wisata Nagari Koto Rantang menurut Wali Nagari.

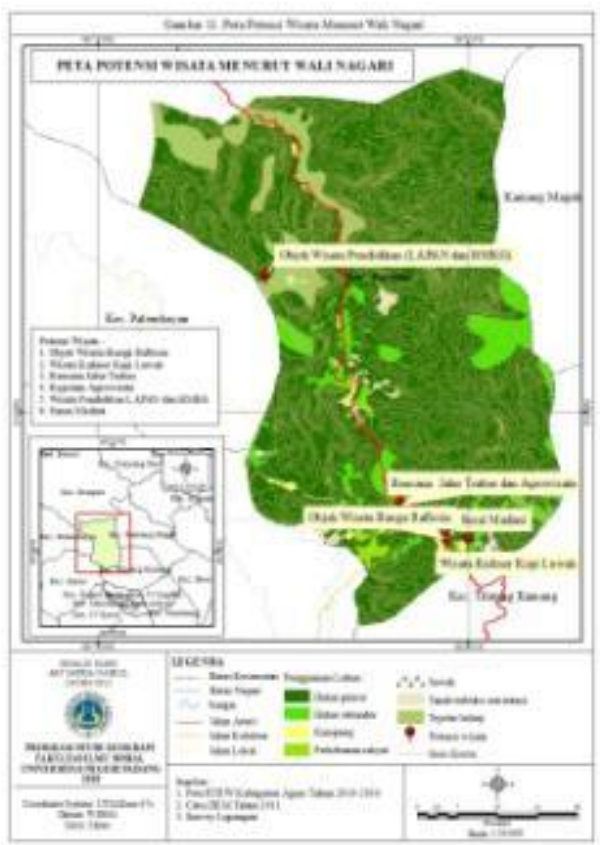

Gambar 2. Potensi Wisata Menurut Wali Nagari

(Sumber : Survey Lapangan)

b. Hasil Wawancara Bersama Wali Jorong

Berdasarkan hasil wawancara yang peneliti lakukan bersama Bapak "Suhatman ST Sati" yang merupakan perangkat desa yang ada di Nagari Koto Rantang menjelaskan mengenai potensi wisata yang ada dinagarinya :

"Bapak yang mewakili semua jorong yang ada di Koto Rantang ini, selalu berharap supaya semua potensi yang ada di Nagari ini dapat dikembangkan karena sebenarnya banyak potensi yang ada disini, seperti saat ini akan dibuat jalur trabas sekaligus membuat kegiatan agrowisata dengan memanfaatkan ladang warga, wisata pendidikan yang sudah ada kerja sama dengan LAPAN dan BMKG yang ada di Nagari Koto Rantang ini, selain itu kita punya surau madani yang bisa dijadikan tempat belajar agama dan adat Minangkabau, dan Nagari Koto Rantang ini punya alam yang indah yang bisa kita jadikan penarik wisatawan untuk berkunjung kesini, kalau menurut bapak itu saja potensi yang bisa dikembangkan selain wisata bunga raflesia dan kopi luwak nak".

Berdasarkan hasil wawancara, maka dapat disimpulkan bahwa menurut Bapak Suhatman ST Sati potensi wisata yang ada di Nagari Koto Rantang tidak jauh berbeda dengan pendapat Bapak SY Datuak Batuduang Dilangik yaitu terdiri dari :

1) Objek wisata bunga raflesia

2) Wisata kuliner kopi luwak

3) Rencana pembuatan jalur trabas

4) Kegiatan agrowisata

5) Wisata pendidikan LAPAN dan BMKG

6) Surau madani

7) Wista pemandangan alam

Gambar 3 merupakan peta potensi wisata Nagari Koto Rantang menurut Wali Jorong. 


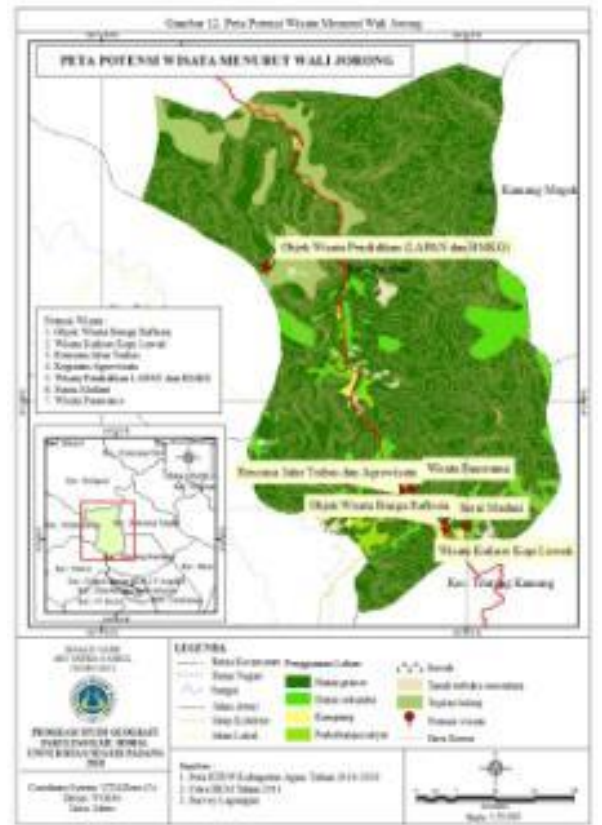

Gambar 3. Potensi Wisata Menurut Wali Jorong

(Sumber : Survel Lapangan)

c. Hasil Wawancara Bersama POKDARWIS Nagari Koto Rantang

Berdasarkan wawancara dengan Bapak "Fitrah Wahyudi" yang merupakan wakil ketua kelompok sadar wisata yang berperan langsung untuk mengelola objek-objek wisata di Nagari Koto Rantang mengenai potensi wisata yang dimiliki nagarinya, yaitu :

"Kami selaku kelompok sadar wisata yang diberikan kepercayaan untuk mengelola pariwisata Nagari Koto Rantang ini selalu berupaya mengembangkan semua potensi wisata yang ada di nagari kami ini, kalau untuk potensi wisatanya mungkin wisata pendidikan yang ada bekerja sama dengan BMKG dan LAPAN, setelah itu ada wisata kopi luwak, bunga raflesia, pembuatan jalur trabas sekaligus nanti dibeberapa spot lokasi trabas itudibuatkan kegiatan agrowisata dengan memanfaatkan ladang masyarakat, nanti kan hasilnya bisa juga untuk menambahnambah pendapatan masyarakat itu sendiri, ada juga surau madani dan alam Koto Rantang yang indah dan asri. Selain itu, tadi adek kan ada melihat didepan kantor walinagari ada lapangan voli, jadi menurut kami olah raga voli juga bisa dijadikan salah kegiatan wisata yang ada".

Berdasarkan hasil wawancara dengan wakil ketua kelompok sadar wisata Nagari Koto Rantang mengenai potensi wisata yang ada dinagari tersebut, diketahui bahwa potensi wisata yang ada terdiri dari :

1) Objek wisata bunga raflesia

2) Wisata kuliner kopi luwak

3) Wisata pendidikan LAPAN dan BMKG

4) Wisata trabas

5) Kegiatan agrowisata

6) Surau madani

7) Wisata pemandangan alam

8) Wisata olah raga voli.

Gambar 4 merupakan peta potensi wisata Nagari Koto Rantang menurut niniak mamak. 


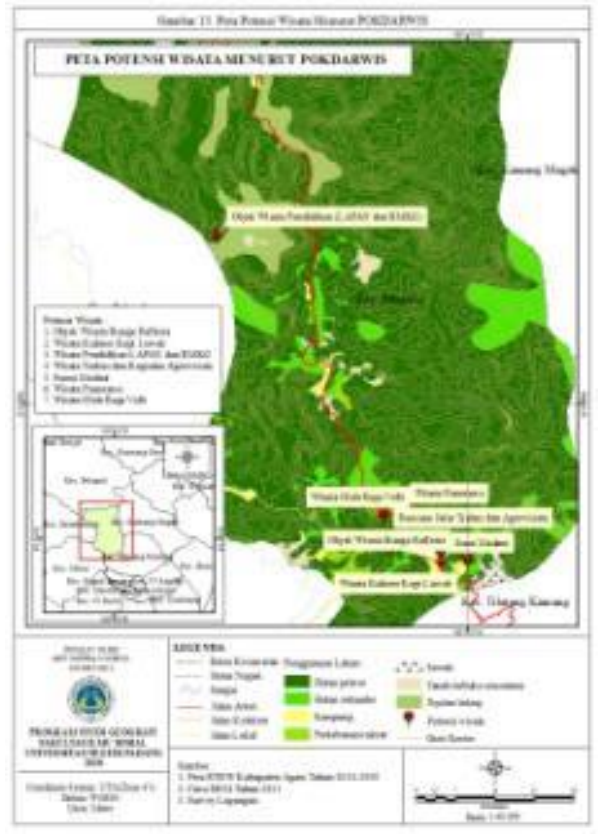

Gambar 4. Potensi Wisata Menurut POKDARWIS

(Sumber : Survey Lapangan)

d. Hasil Wawancara Bersama Niniak Mamak

Berdasarkan wawancara dengan niniak mamak yang biasa dipanggil pak "Niniak" yang merupakan salah satu pemuka adat yang ada di Nagari Koto Rantang mengenai potensi wisata yang dimiliki nagarinya, ia mengatakan sebagai berikut :

"Di Nagari Koto Rantang inikaya akan potensi alamnya, Cuma kalau bapak lihat masih belum terlalu terorganisir, sebab untuk kelompok sadar wisata pun baru dikukuhkan sekitar awal tahun kemaren nak, kalau menurut bapak potensi yang bisa dikembangkan itu seperti bunga raflesia dengan kopi luwak yang memang menjadi ikon nagari ini, selain itu saat ini masyarakat berencana membuat jalur trabas dan ada juga wisata pendidikan yang sudah dijalin hubungan yang baik antara pemerintah nagari, masyarakat serta kelompok sadar wisata yang dengan pihak
LAPAN dan BMKG, disi juga ada surau yang biasa dijadikan tempat belajar ngaji sekaligus tempat musyawarah dan saat ini surau itu sudah mulai diaktif kembali, kalau untuk kesenian adat saat ini masyarakat sudah mulai belajar randai nak".

Berdasarkan hasil wawancara, maka dapat disimpulkan bahwa menurut pak niniak potensi wisata yang ada di Nagari Koto Rantang terdiri dari :

1) Objek wisata bunga raflesia

2) Wisata kuliner kopi luwak

3) Rencana pembuatan jalur trabas

4) Wisata pendidikan LAPAN dan BMKG

5) Suarau madani, dan

6) Kesenian Randai

Gambar 5 merupakan peta potensi wisata Nagari Koto Rantang menurut Wali Nagari.

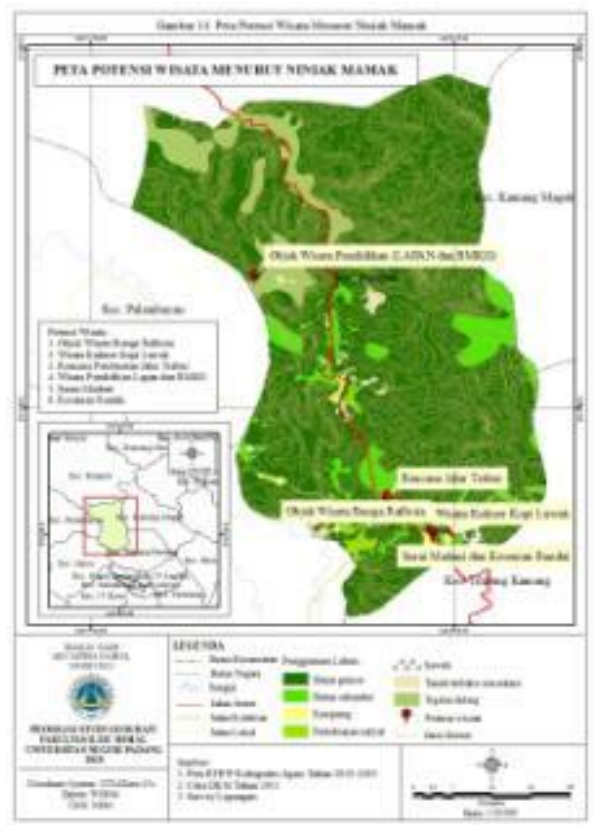

Gambar 5. Potensi Wisata Menurut Niniak Mamak

(Sumber : Survey Lapangan)

e. Potensi Wisata Bersadarkan Pengamatan Lapangan 
Berdasarkan pengematan dilapangan dan informasi yang peneliti poroleh dari berbagai sumber, maka peneliti merangkum potensi wisata yang dimiliki Nagari Koto Rantang sebagai berikut :

1) Objek wisata bunga raflesia

2) Wisata kuliner kopi luwak

3) Pembuatan jalur trabas

4) Kegiatan agrowisata seperti kebun buah

5) Wisata pendidikan LAPAN dan BMKG

6) Surau madani

7) Wisata panorama

8) Kesenian randai

9) Agrowisata sebagai pusat pemasok rempah-rempah yang ada di Kabupaten Agam

10) Kegiatan hiking

Gambar 6 merupakan peta potensi wisata Nagari Koto Rantang menurut survey lapangan.

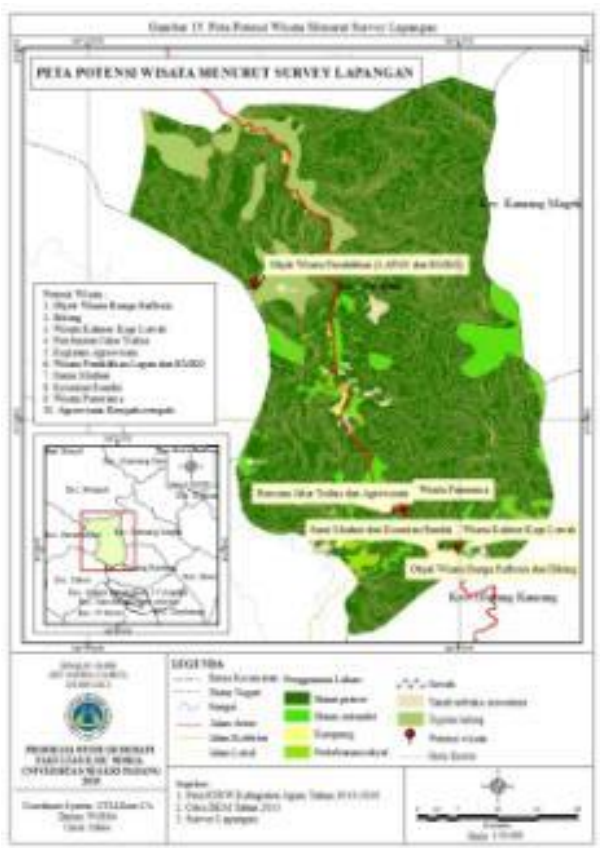

Gambar 6. Potensi Wisata Menurut Survey Lapangan

(Sumber :Survey Lapangan)
Berdasarkan penarikan kesimpulan hasil wawancara dengan keempat informan kunci, maka diperoleh data potensi wisata Nagari Koto Rantang yang disajikan pada gambar 7 dalam bentuk peta sebagai berikut :

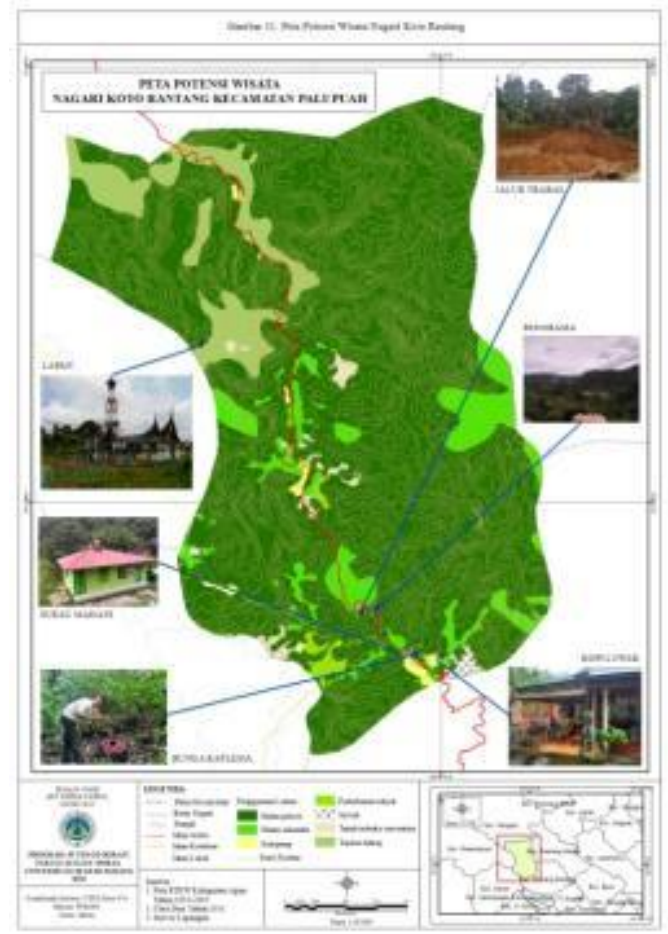

Gambar 7. Potensi wisata Nagari Koto Rantang

(Sumber: hasil analisis data)

Berdasarkan informasi yang diperoleh peneliti dari wawancara bersama informan kunci, kemudian peneliti melakukan penyederhanaan data dengan memilih informasi yang di anggap mewakili dan dapat dipercaya mengenai potensi wisata Nagari Koto Rantang yang dijabarkan sebagai berikut :

a. Wisata Bungan Raflesia

Objek wisata bunga raflesia merupakan salah satu wisata andalan yang dimiliki Nagari Koto Rantang. Bunga raflesia pada saat mekar diameternya mencapai 70 hingga 110 
$\mathrm{cm}$ dengan tinggi mencapai $50 \mathrm{~cm}$ dan berat hingga $11 \mathrm{~kg}$. Bunga bangkai raksasa ini merupakan salah satu spesies tumbuhan langka yang ada di Indonesia bahkan di dunia, inilah yang menjadi salah satu daya tarik wisatawan manca negara untuk berkunjung ke Nagari Koto Rantang

Lokasi objek wisata bunga raflesia sendiri saat ini dikelola oleh masyarakat yang membentuk Kelompok sadar wisata Nagari Koto Rantang di bawah nauangan pemerintah Nagari, Kecamatan dan Dinas Pariwisata Pemudan dan Olah Raga Kabupaten Agam.

Objek wisata bunga raflesia ini memang sudah terkenal, selain sudah banyaknya wisatawan nasional dan wisatawan mancanegara seperti Australia, Singapore, Cina dan Jepang di lokasi objek bunga raflesia ini juga sudah sering dijadikan lokasi syuting, terakhir pada Bulan Januari 2017 adalah syuting yang dilakukan oleh salah satu stasiun televisi luar negri yaitu SBS Korea yang berjudul law of the jungle.

Untuk menuju hutan raflesia nantinya kita akan di pandu oleh guide atau masyarakat yang menjadi pemandu jalan disana. Selama di perjalanan menuju lokasi hutan raflesia yang dilakukan dengan tracking selama \pm 1 jam perjalanan wisatawan akan dimanjakan dengan pemandangan hijau nya hamparan sawah masyarakat serta masi asri nya hutan yang ada disana.

b. Wisata Kopi Luwak

Selain bunga raflesia, kopi luwak juga merupakan salah satu ikon dari wisata yang dimiliki Nagari Koto Rantang. lokasi kopi luwak ini berda di kawasan objek wisata bunga raflesia. Usaha ini dikembangkan oleh salah satu warga Nagari Koto Rantang karena warga tersebut melihat adanya peluang dari wisatawan yang berkunjung ke objek wisata bunga raflesia. Dengan memanfaatkan jasa wisatawan yang berkunjung untuk melihat bunga raflesia di Nagari Koto Rantang ini, pemasaran kopi luwak ini telah mencapai negara yang ada di kawasan Asia, Eropa, Amerika dan Australi.

Kopi luwak di Nagari Koto Rantang memiliki ciri khas tersendiri, dikarenakan proses pembuatan nya yang dimulai dari biji kopi yang dimakan oleh luwak atau musang liar yang menjadi kotoran yang kemudian kotoran tersebut dikeringkan dan diolah menjadi kopi. Luwak liar biasanya hanya memakan tumbuhan yang ada di habitatnya, sehingga biji kopi yang langsung dimakan oleh luwak liar dianggapa memiliki kandungan enzim yang lebih tinggi dibandingkan dengan kopi yang bersal dari luwak yang dikandangkan.

Pada objek wisata kopi luwak ini wisatawan tidak hanya dapat meminum kopi tersebut, namun dilokasi ini kita juga bisa melihat dan ikut serta dalam proses pengolahan kopi luwak yang sudah dikeringkan tersebut. tidak hanya itu saja, kopi luwak yang sudah di olah juga bisa dijadikan lulur kopi dianggap bagus untuk perawatan kulit. Selain adanya kopi luwak organik wisatawan juga di berikan paket untuk belajar memasak masakan khas Sumatera Barat seperti rendang daging, rendang daging bebek, gulai ayam, serta samba lado. 
c. Jalus Trabas dan Agrowisata

Tidak puas hanya dengan objek wisata bunga raflesia dan kopi luwak saja, pemerintah dan masyarakat Nagari Koto Rantang berkeinginan untuk menggali segala potensi wisata yang ada di nagari tersebut. Saat ini pemerintah dan masyarakat sedang melakukan pembentuk jalur trabas yang tepat berlokasi di belakang kantor wali nagari Koto Rantang guna pengembangan potensi desa wisata di Nagari Koto Rantang.

Jalur ini dibangun di atas lahan masyarakat yang telah dibebaskan. Masyarakat bahkan berencana membentuk kawasan agrowisata pada daerah yang dilewati jalur trabas tersebut. Pembentukan kawasan agrowisata pada daerah yang dilalui jalur trabas dimaksudkan agar nantinya para pengunjung yang mengikuti kegiatan rail tracking atau trabas bisa dimanjakan dengan adanya paket wisata yang menawarkan wisatawan untuk langsung bisa memetik hasil kebun dari masyarakat yang ada di sepanjang jalur trabas tersebut, selain itu nanti wisatawan juga akan dimanjakan dengan adanya pemandangan alam Nagari Koto Rantang dari ketinggian.

d. Wisata Pendidikan LAPAN dan BMKG

Selain wisata alam Nagari Koto Rantang juga memiliki potensi wisata pendidikan. Dengan berdirinya BMKG (Badan Meteorologi Klimatologi dan Geofisika) dan LAPAN (Lembaga Penerbangan dan Antariksa Nasional) pemerintah dan masyarakat berencana untuk bekerja sama dengan pihak tersebut guna menjadikan lembaga tersebut sebagai objek wisata pendidikan.

LAPAN dan BMKG Koto Tabang merupakan lembaga riset dan penelitian kedirgantaraan. Penelitiannya membahas tentang fisika atmosfer, yang meliputi arah dan kecepatan angin, curah hujan, kelembaban, lapisan ionosfer sebagai pemantulan gelombang radio, data-data tentang awan, aerosol atau debu dan sebagainya. Data ini berguna untuk penelitian tentang berbagai bidang.

LAPAN dan BMKG Koto Tabang dibangun untuk melegkapi data pengamatan atmosfer dan ionosfer wilayah Indonesia. Data ini nantinya diperlukan untuk memperoleh pemahaman yang lebih baik mengenai fenomena atmosfer dan ionosfer khatulistiwa, sehingga peristiwaperistiwa anomali atau gangguangangguan atmosfer dan ionosfer dapat diantisipasi lebih dini dengan baik. Wisatawan bisa memperoleh atau menambah ilmu pengetahuan yang berkaitan dengan atmosfer dan ionosfer dengan dijdikannya LAPAN sebagai objek wisata pendidikan.

e. Panorama Koto Rantang

Koto Rantang merupakan nagari yang memiliki topografi yang beragam, hal itu menjadikan Nagari Koto Rantang memiliki banyak spot yang bisa dijadikan sebagai lokasi panorama. Di salah satu lokasi yang berpotensi menjadi panorama, saat ini sudah dibuka beberapa usaha-usaha dibidang kuliner yang disediakan untuk menemani wisatawan menikmati pemandangan alam yang dimiliki Nagari Koto Rantang. 


\begin{tabular}{|c|c|c|c|c|c|c|}
\hline \multicolumn{7}{|c|}{ HEADER } \\
\hline Menu & Menu 1 & Menu 2 & Menu 3 & Menu 4 & Menu 5 & Menu 6 \\
\hline & & & & & \multicolumn{2}{|c|}{ Sidebar Right 1} \\
\hline & & & & & \multicolumn{2}{|c|}{ Sidebar Right 2} \\
\hline & & & & & \multicolumn{2}{|c|}{ Sidebar Right 3} \\
\hline FOOT & & & & & & \\
\hline
\end{tabular}

memiliki keunggulan dan manfaat selain pemandangan yang indah, panorama ini juga berada di pinggir jalan yang nantinya sangat bermanfaat bagi para pengguna jalan yang melewati jalur lintas Bukitinggi-Sumatera Utara sebagai lokasi peristirahatan untuk melepas penat sambil menikmati pemandangan alam dan suguhan kuliner yang desediakan oleh masyrakat sekitar panorama tersebut.

\section{Weblog Wisata Nagari Koto Rantang}

Pengembangan desa wisata berbasis weblog ini bertujuan untuk menginformasikan kepada wisatawan mengenai kegiatan-kegiatan wisata yang ada di Nagari Koto Rantang baik wisata alam, buatan, kuliner maupun wisata pendidikan.

Berdasarkan hasil pengolahan data penelitian mengenai pengembangan potensi desa wisata berbasis weblog di Nagari Koto Rantang yang telah dilakukan, maka dapat dibangun sebuah weblog Nagari Koto Rantang.

a. Desain Tampilan Weblog

Desain tampilan weblog harus dibuat semenarik mungkin namun juga harus mempermudah wisatawan untuk memahami informasi yang disajikan di dalam weblog tersebut.

\section{Keterangan :}

$$
\begin{aligned}
\text { Header }= & \text { Judul blog } \\
\text { Menu }= & \text { Beranda } \\
\text { Menu } 1= & \text { Profil nagari } \\
\text { Menu } 2= & \text { Deskripsi wisata alam } \\
\text { Menu } 3= & \text { Deskripsi wisata kuliner } \\
\text { Menu } 4= & \text { Deskripsi wisata } \\
& \text { pendidikan } \\
\text { Menu } 5= & \text { Deskripsi paket wisata } \\
\text { Menu } 6= & \text { Download peta }, \text { berisi peta } \\
& \text { pariwisata }
\end{aligned}
$$

\section{Sidebar}

$$
\begin{aligned}
\text { Right } 1= & \text { Peta Nagari Koto Rantang } \\
& \text { hasil link Google Map }
\end{aligned}
$$

\section{Sidebar}

Right 2 = Foto objek wisata

\section{Sidebar}

$$
\begin{aligned}
\text { Right } 3= & \text { video mengenai Nagari } \\
& \text { Koto Rantang } \\
\text { Footer }= & \text { Batas blog }
\end{aligned}
$$

Berikut dibawah ini merupakan hasil penyusunan weblog Nagari Koto Rantang berdasarkan desain tampilan blog yang telah dibentuk pada halaman sebelumnya. 


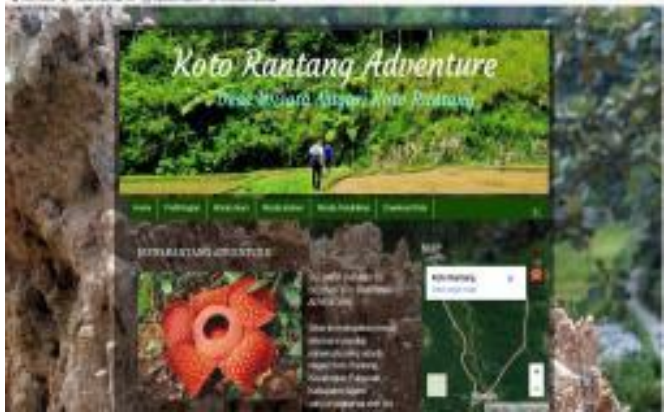

Gambar 8. Tampilan Menu Utama Blog

Desa Wisata Nagari Koto Rantang (Sumber : Hasil Penyusunan Weblog Nagari Koto Rantang)

Berdasarkan gambar 8 di atas dapat dilihat bentuk halaman utama dari tampilan blog Nagari Koto Rantang, yang terdiri dari menu-menu yang menyajikan informasi pariwisata Nagari Koto Rantang.

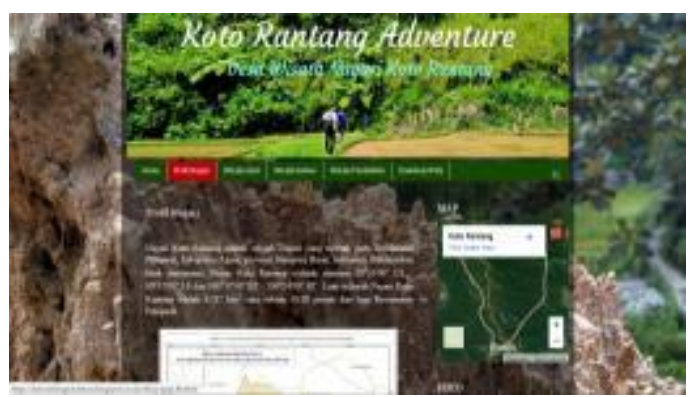

Gambar 9. Tampilan Menu 1 Mengenai Profil Nagari Koto Rantang

(Sumber : Hasil Penyusunan Weblog Nagari Koto Rantang)

Pada gambar 9 ini pengunjung blog dapat melihat profil nagari dengan memilih menu "profil" yang menjelaskan tentang deskripsi wilayah Nagari Koto Rantang. salain itu, informasi mengenai profil nagari juga disajikan dalam bentuk peta administrasi dan batas Nagari Koto Rantang dengan nagari-nagari lainnya

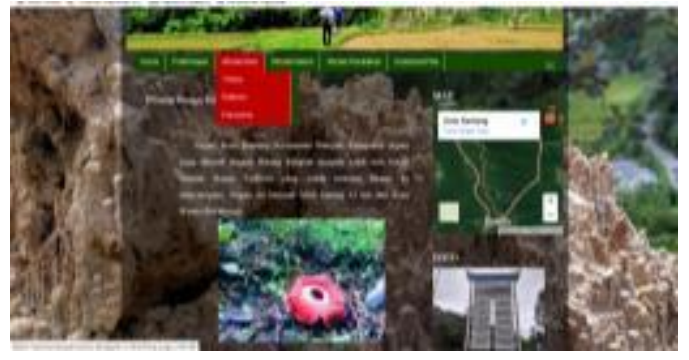

Gambar 10. Tampilan Menu 2 Mengenai Wisata Alam Nagari Koto Rantang

(Sumber : Hasil Penyusunan Weblog Nagari Koto Rantang)

Pada gambar 10 blog ini menjelaskan tentang wisata alam, didalam menu ini menjelaskan tiga objek wisata alam yang terdiri dari wisata bunga raflesia, objek wisata trabas, dan objek wisata panorama.

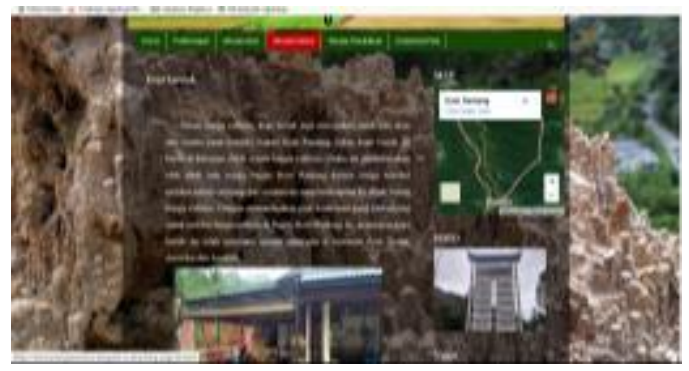

Gambar 11. Tampilan Menu 3

Mengenai Wisata Kuliner Nagari Koto Rantang

(Sumber : Hasil Penyusunan Weblog Nagari Koto Rantang)

Pada gambar 11 dapat dilihat deskripsi tentang objek wisata kuliner kopi luwak, dimana menu ini menjelaskan deksripsi tentang wisata kuliner berserta kegiatan yang ada pada objek wisata ini mulai dari kopi yang dapat di cicipi hingga cara pengolahan kopi luwak.

Selanjutnya dibawah ini merupakan gambar 17 mengenai potensi wisata pendidikan LAPAN yang 
bergerak dibidang antariksa dan penerbangan luar angkasa.

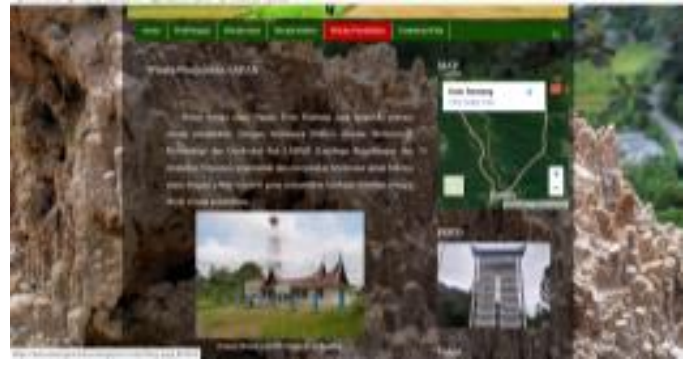

Gambar 12. Tampilan Menu 4 Mengenai Wisata Pendidikan Nagari Koto Rantang

(Sumber : Hasil Penyusunan Weblog Nagari Koto Rantang)

Pada gambar 12 blog dapat memberikan informasi tentang kegiatan pariwisata yang ada di objek wisata Lapan dan BMKG, dimana lokasi ini di jadikan tempat wisata berkat kerja sama antara pemerintah Nagari koto rantang dengan pihak Lapan dan BMKG.

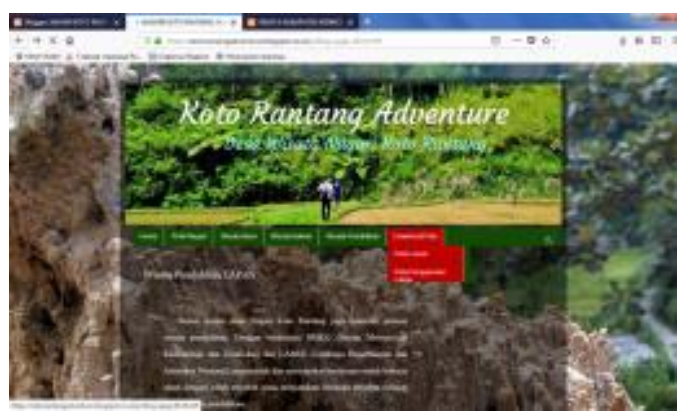

Gambar 13. Tampilan Menu 6

Mengenai Download Peta Pariwisata Nagari Koto Rantang

(Sumber : Hasil Penyusunan Weblog Nagari Koto Rantang)

Pada gambar 13 ini menu pada blog menjelaskan tentang peta objek wisata Nagari Koto Rantang dan peta peta penggunaan lahan yang telah dilakukan pengolahan data yang di dapat di lapangan dan dilanjutkan menggunakan software ArcGIS 10.1

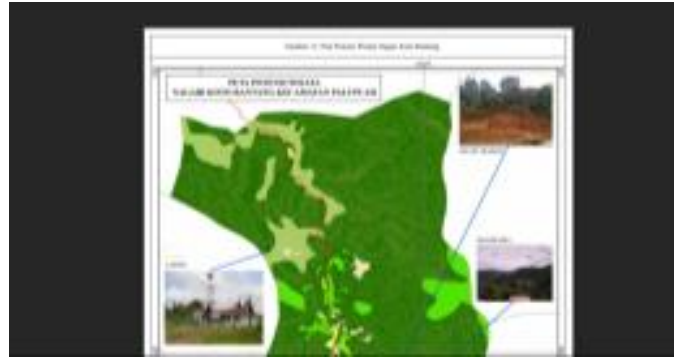

Gambar 14. Tampilan Link

Download Peta Potensi Nagari Koto Rantang

(Sumber : Hasil Penyusunan Weblog Nagari Koto Rantang)

Pada gamabr 14 ini adalah bentuk peta yang dapat dibuka pada menu peta, disini nantinya pengunjung blog dapat mendownload peta yang sudah di masukin link saat mendesain.

\section{PENUTUP}

\section{Kesimpulan}

Berdasarkan deskripsi data dan pembahasan hasil penelitian yang telah dikemukakan pada bab IV maka dapat diambil kesimpulan tentang penginformasian potensi desa wisata berbasis weblog di Nagari Koto Rantang Kecamtan Palupuh Kabupaten Agam sebagai berikut:

a. Nagari Koto Rantang memiliki banyak potensi wisata baik dari sektor alam, kuliner dan pendidikan seperti Bunga Raflesia, panorama ,pembuatan jalur trabas, kopi luwak dan wisata pendidikan LAPAN. Dari seluruh wisata tersebut nantinya dapat memicu daya tarik wisatawan untuk sering berkunjung ke Nagari Koto Rantang.

b. Pengembangan desa wisata berbasis weblog ini bertujuan untuk menginformasikan kepada wisatawan mengenai kegiatan-kegiatan wisata yang ada di Nagari Koto Rantang 
baik wisata alam, buatan, kuliner maupun wisata pendidikan. Pembuatan weblog wisata ini juga bermaksud memberikan informasi mengenai paket-paket wisata yang ditawarkan serta dapat dijadikan panduan bagi wisatawan untuk mengikuti berbagai kegiatan wisata yang disajikan kepada wisatawan.

\section{Saran}

a. Nagari Koto Rantang memiliki banyak potensi wisata yang dapat dikembangkan selain wisata bunga raflesia dan kopi luwak yang saat ini menjadi objek andalan nagari tersebut. Oleh karena itu, perlu adanya dukungan penuh oleh seluruh masyarakat Nagari Koto Rantang guna mendukung pembentukan dan pengembangan kegiatan wisatanya, karena untuk kedepannya potensi wisata nagari tersebut dapat mmberikan dampak positif bagi perkembangan dan sumber pemasukan untuk nagari serta masyarakat setempat.

b. Pembutan blog wisata merupakan salah satu cara atau media promosi yang bisa digunakan sebagai upaya untuk mengembangakan serta memajukan potensi wisata yang dimiliki suatu nagari, dengan adanya blog wisata, wisatawan yang berasal dari berbagai daerah bahkan luar negeri bisa mengakses dan melihat review suatu objek wisata sebelum mengunjunginya, seperti paket wisata yang ditawarkan, lokasi, akses serta objek-objek wisata yang dimilikinya.

\section{DAFTAR PUSTAKA}

Edwin, G. (2015). Studi Tentang Pembentukan Desa Setulang Sebagai Desa Wisata Dikecamatan Malinau Selatan Hilir Kabupaten Malinau. 152163.

Perundang-undangan, K. B. (2009). Undang-undang Nomor 10 Tahun 2009 tentang kepariwisataan. Jakarta: Menteri Hukum dan Hak Asasi Manusia.

Ramadan, J. (2017, April 30). Aktivitas Wisata di Palupuh Buka Peluang Usaha Baru . Retrieved Mei 20, 2017, from Agam Media Center: http://www.Agammediacenter.co m/2017/03/Aktivitas Wisata di Palupuh Buka Peluang

Harry dan Harmen. (2017, April 1). POKDARWIS Raflesia Dikukuhkan. Retrieved September 8, 2017, from Kaba12.co.id: http://kaba12.co.id/2017/04/01/p okdarwis-raflesia-dikukuhkan/

Mulyadin, S. P. (2001). Pembangunan Desa Wisata : Pelaksanaan Undang-Undang Otonomi Daerah. Jurnal Sosial Ekonomi , 38.

Purnomo, A. T. (2015). Partisipasi Masyarakat Dalam Rencana Pembangunan Desa Wisata di Desa Limbasari Kecamatan Bobotsari Kabupaten Purbalingga. 58. 